\title{
Post-Asean Agreement on Transboundary Haze Pollution: How to Settle the Dispute Settlement?
}

\author{
Fadia Fitriyanti', Yordan Gunawan ${ }^{2}$ \\ ${ }^{1}$ Faculty of Law, Universitas Muhammadiyah Yogyakarta, Indonesia. E-mail: yantifadia@umy.ac.id \\ 2 Faculty of Law, Universitas Muhammadiyah Yogyakarta, Indonesia. E-mail: yordangunawan@umy.ac.id
}

\begin{abstract}
ARTICLE INFO
Keywords:

International Law;

Pollution; Ratification;

State Responsibility;

Transboundary Haze

Pollution

How to cite:

Fitriyanti, F., Gunawan,

Y. (2019). Post-Asean

Agreement on

Transboundary Haze

Pollution: How to Settle

the Dispute Settlement?,

Hasanuddin Law Review,

5 (3): 253-265

DOI:

10.20956/halrev.v3i3.1541
\end{abstract}

\section{Introduction}

Environmental problems that occur in a particular country or region will also affect other countries or regions. This is due to environmental pollution, as a concrete example is forest fires, which the impact is not only experienced by the country affected by the pollution, but also in the neighboring countries. This can be caused by natural factors that significantly affect transboundary haze pollution, because storm

\begin{abstract}
Forest fire happened several times in Indonesia which impacting neighboring countries, such as Malaysia and Singapore. ASEAN tried to "heal" and prevent the possibility of similar events by signing the ASEAN Agreement on Transboundary Haze Pollution (AATHP) for its members. In line with that, this research examined the concern of the state responsibility principle and its dispute resolution as well as a mechanism under the Agreement in dealing with the transboundary haze pollution in ASEAN. The research conducted by using normative theory by using primary, secondary and tertiary legal materials, collected from library research. Data analysis uses statute approach and case approach. Furthermore, the resulting research is in the form of analytical descriptive. The researchers argue that AATHP it is not explained in detail about the forms, mechanisms, and consequences that can be given to a country that has caused forest fires in the national jurisdiction and proven damage other countries. The researchers conclude that there should be a clear definition of state responsibility by means of a visible dispute settlement. Those mentioned steps are aimed to prepare for both preventive and punitive legal action for all members of ASEAN in dealing with the case of transboundary haze pollution.
\end{abstract}

Copyright $\odot 2019$ HALREV. All rights reserved. 
and wind patterns are able to bring haze pollution from one location to a wider area, even crossing national borders. ${ }^{1}$

The direct impact of forest fires was among others the first emergence of acute respiratory infections in the community. The second reduces work efficiency because when all forest fires occur, the office is closed. The third is the disruption of land, sea and air transportation. Fourth, the emergence of international problems of haze creates material and immaterial losses for people affected by the haze and pollution of haze across borders. The five decreases in air quality and visibility. ${ }^{2}$ The most serious impacts of forest fires and haze pollution are related to human health arising from certain chemical substances that enter the human body, whether they are from contaminated water, contaminated food, or inhaled air. It's no longer worth it. In 1997 and 1998 alone, there were around 7.5 million people in six Southeast Asian countries involving Indonesia, Singapore, Thailand, Brunei, the Philippines and Malaysia who was affected by haze pollution. ${ }^{3}$

As turns out into practice, it can be seen in Indonesia that every year, there are forest fires in Sumatra and Kalimantan, the impact of these forest fires is also felt by the people of neighboring countries, namely Singapore and Malaysia. 4 As a result of forest fires caused haze blankets in Southeast Asia on September 6, 19975 and even becoming regular event for ASEAN (Picture 1). In fact, according to Helena Varkkey, forest fires in Indonesia have been widely recorded since the nineteenth century. ${ }^{6}$

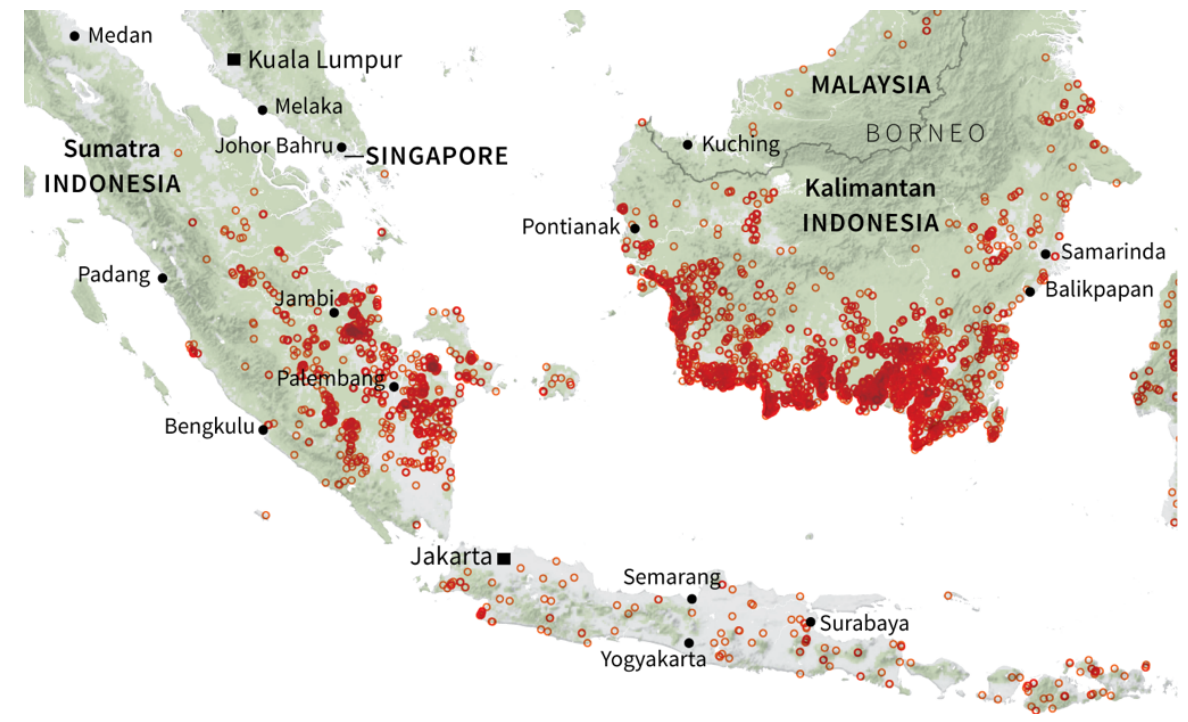

\footnotetext{
1 Jerger, David B. Jr. (2014). “Indonesia's Role in Realizing the Goals of ASEAN's Agreement on Transboundary Haze Pollution". Sustainable Development Law and Policy, 35.

2 Akbar Kurnia Putra. (2015). “Transboundary Haze Pollution dalam Perspektif Hukum Lingkungan Internasional", Jurnal Ilmu Hukum, 1(1): 95

3 Wan Fairus Wan Yacob et all. (2016), "The Impact of Haze on the Adolescent's Acute Respiratory Disease: A Single Institution Study". Journal of Acute Disease, 5(3):27

4 Supriadi. (2010). Hukum Lingkungan di Indonesia. Jakarta: Cetakan ketiga, Sinar Grafika, Jakarta, p. 42.

5 Judith Mayer. (2006) "Transboundary Perspectives on Managing Indonesia's Fires", Journal of Environmental and Development, 15(2): 203

6 Helena Varkkey.(2013), "Patronage Politics, Plantation Fires and Transboundary Haze”, Environmental Hazards, 12(3-4):201
} 


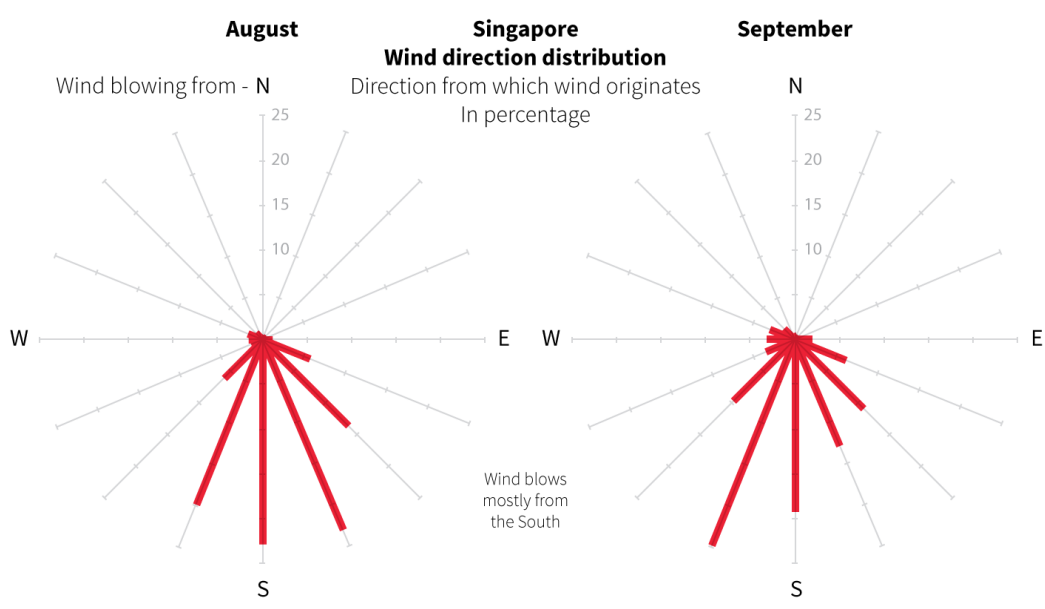

Picture 1. Forest fire spot burned across nations and wind patterns. ${ }^{7}$

Recognizing the importance of preventing environmental impacts from neighboring countries, countries in certain regions need to conduct a cooperation agreement or agreement to find solutions to the impacts arising from environmental pollution. To realize the cooperation in the environmental field, on April 30, 1981, in Manila, the first meeting of the Environment Ministers was held which succeeded in establishing environmental policies for the ASEAN region. The ASEAN Ministers' collective agreement was stated in the form of the Manila Declaration on the ASEAN environment. ${ }^{8}$

Then the problem of haze pollution at the Regional level was discussed again at a meeting of the ASEAN Environment Ministers and embodied in the agreement of the ASEAN Environment Minister on June 19, 1990. In order to overcome the haze problem, in 1995 ASEAN negotiated cooperation in the form of the ASEAN Cooperation Plan on Transboundary Pollution. ${ }^{9}$ This agreement was further elaborated in the ASEAN Cooperation Plan on Transboundary Haze Pollution in 1995. The Cooperation Plan includes procedures and mechanisms for cooperation in preventing and overcoming cross-border haze pollution. 10 Then, the Ministers of Environment of ASEAN Countries formulated regional plans to address the problem of forest fires, known as the Regional Haze Action Plan in 1997. These transboundary haze pollution events were then discussed at the ASEAN level and resulted in the 1997 Hanoi Plan of Action which included efforts to overcome the problem of pollution of cross-border borders as a result of land and/or forest fires. To formalize the plan of ASEAN cooperation on transboundary haze pollution in 1995 and make effective the Hanoi

\footnotetext{
7 Thomson Reuters. (n.d.). Southeast Asian Haze. Reuters Graphics. Retrieved from http://graphics.thomsonreuters.com/15/haze/index.html (30 August 2019)

8 Siti Sundari Rangkuti. (2000). Hukum Lingkungan dan Kebijaksanaan Lingkungan Nasional. Surabaya: Airlangga University Press, Third edition, p.47

9 The Jakarta Post. (2015). Why Indonesia must ratify the ASEAN haze pollution treaty. Available online from http://www.thejakartapost.com/news/2013/07/14/why-indonesia-must-ratify-asean-haze-pollution-treaty.html. [Accessed March Maret 17,2015]

10 Law No. 26 of 2014 concerning Ratification of the ASEAN Agreement on Transboundary Haze Pollution.
} 
Plan of Action 1997 ASEAN members agreed to make the ASEAN Agreement on Transboundary Haze Pollution as a joint commitment.11

In 2002 the ASEAN agreement was signed and effective in 2007. The ASEAN Agreement on Transboundary Haze Pollution monitors and prevents haze pollution through various forms of agreed cooperation. The Malaysia and Singapore protests are connected to the reason that the haze has caused disturbances to public health, their economy, and tourism, even Malaysia have criticized Indonesia for not being able to overcome the haze problem and Indonesia must pay compensation due to haze.12 This statement also supported by Singapore which its Law makers has been doing "weapon" targeted for those who fire burning for theirs business. That was actually initiated since Indonesia, again, become the 'pioneer' of the forest fire maker. ${ }^{13}$

Then, in 2002 ASEAN adopted the ASEAN Agreement on Transboundary Haze Pollution (AATHP), namely the Collaboration Agreement on Transboundary Haze Pollution which aims to prevent and monitor cross-border haze pollution from forest and land fires. This goal is explicitly contained in Article 2 AATHP: "The objective of this Agreement is to prevent and monitor transboundary haze pollution as a result of land and or forest fires which should be mitigated, through concerted national efforts and intensified regional and international cooperation. This should be in the overall context of sustainable development and in accordance with the provisions of this Agreement. "

Furthermore, air pollution caused by forest fires is contrary to the principles of international environmental law. One principle is "Sic utere tuo ut alienum non laedes" which determines that a State is prohibited from carrying out or permitting activities that can harm other countries, 14 and the principle of good neighborliness. ${ }^{15}$ In essence, the principle says that the territorial sovereignty of a country must not be disturbed by other countries.

In the case of AATHP ratification, every ASEAN meeting, Indonesia is always faced with the question of when to ratify AATHP and only be present as observers who do not have voting rights. This, of course, weakens Indonesia's position which has so far played an active role in determining the direction of ASEAN regional policies. Considering the benefits Indonesia obtained through the ratification of the AATHP, then at the end of the 2009-2014 Indonesian House of Representatives period, the Bill on Ratification of AATHP was re-discussed since it was first proposed by the Legislative Body in 2006. Through the DPR Plenary Session September 16, 2014, finally, the AATHP ratification officially became Law Number 26 of 2014 concerning Ratification of the ASEAN Agreement on Transboundary Haze Pollution.

Apart from the reasons that caused Indonesia to become the last AATHP ratification country, the ratification of the Law on the Endorsement of AATHP was a step forward for Indonesia to show its seriousness in overcoming forest and land fires. The problem

1 Loc.cit

12 Kuala Lumpur Suara Karya Online. (2015). http://www.suarakaryaonline.com/news.html?id=118116, [Accessed 17,March]

13 Daniel Melling. (n.d). STATEMENT: Singapore's New Haze Pollution Law "A New Way of Doing Business". World Research Institute. https://www.wri.org/news/2014/08/statement-singapore\% E2\% 80\% 99s-newhaze-pollution-law-\% E2\% 80\% 9C-new-way-doing-business\%E2\%80\% 9D (30 August 2019).

14 J.G. Starke.(1992).Pengantar Hukum Internasional, Jakarta:Sinar Grafika, p. 546

15 Sucipto. (1985). Sistem Tanggung Jawab Dalam Pencemaran Udara, Malang, p. 82. 
of haze which has been cornered Indonesia as a source state, some of its responsibilities will be the joint responsibility of ASEAN countries. ${ }^{16}$

If it is very important to review and examine how the state's responsibility for transboundary haze pollution post-AATHP? And how is the legal settlement mechanism for transboundary haze pollution within ASEAN post-AATHP? Preliminary studies on this subject have been examined by Deni Bram, ${ }^{17}$ regarding State Responsibility for Transnational Environmental Pollution, in 2011, the difference with the results of research conducted by the researcher that there are differences in the concepts of state responsibility according to transnational law and international environmental law on the issue of transboundary haze pollution. The limits and mechanism for resolving environmental pollution disputes that are transnational in nature, do not discuss AATHP. Whereas the research conducted by Yordan Gunawan in 2016, concerning Indonesian Responsibility for Transboundary Haze Pollution after the Ratification Asean on Transboundary Haze Pollution (AATHP), ${ }^{18}$ where this study did not discuss the Theory of State Responsibility post-Asean Agreement on Transboundary Haze Pollution, the only focus discuss Indonesian Responsibility afterAATHP.

\section{Method}

The research method used in this study is normative juridical research from library research, the material used is primary, secondary and tertiary legal materials. Data analysis uses statute approach and case approach. Furthermore, the research produced was in the form of analytical descriptive

\section{The Review of the Dispute Settlement against Transboundary Haze Pollution after-AATHP Ratification}

International dispute resolution can be carried out in various ways, namely peace, violence, and war. Peaceful settlement of disputes can be seen in Article 33 paragraph 1 of the UN Charter, namely by negotiation, inquiry, mediation, conciliation, arbitration, legal judicial settlement). If a dispute occurs and it turns out the parties cannot resolve the dispute peacefully, thus causing one of the parties to be forced to take unilateral action. The action was taken to achieve its objectives by benefiting its own side, which is an act of coercion in the form of pressure so that other parties feel forced to accept the will. In international law known some form of coercive measures, namely retorsion, reprisals, pacific blockade, intervention, war and armed action was not war and nonwar armed action. War is the last method taken by the party to the dispute where one party forces another to accept the settlement of the dispute he wants. ${ }^{19}$

16 Teddy Prasetiawan.( 2014), “Implikasi Ratifikasi AATHP Terhadap Pengendalian Kebakaran Hutan dan Lahan Indonesia", Info Singkat, VI:19/1/P3DI/Oktober/2014, Pusat Pengkajian, Pengolahan Data dan Informasi (P3DI), Sekretariat Jenderal DPR RI, Jakarta, VI(19):11.

17 Deni Bram. (2010). Pertanggungjawaban Indonesia terhadap pencemaran kabut asap di kawasan ASEAN (pendekatan economic analysis of law). Jurnal Hukum dan Pembangunan.40(40):231

18 Yordan Gunawan. (2014). Indonesian Responsibility for transboundary Haze Pollution After the Ratification Asean on Transboundary Haze Pollution (AATHP). Jurnal Media Hukum. 21(2): 170-177.

19 Sri Setianingsih Suwardi. (2006). Penyelesaian Sengketa Internasional, Jakarta: Universitas Indonesia (UI-Press), p. 15-196 
The dispute resolution in ASEAN countries is regulated in the Treaty of Amity and Cooperation in SouthEast ASEAN Nations (TAC). In the preamble, TAC reads: The settlement of differences or disputes between their countries should be regulated by rational, effective and efficient, flexible procedures, avoiding negative attitudes which might end on hinder cooperation. To realize these ideals, the regulation regarding dispute resolution is regulated in Chapter IV TAC Article 13-17.

Article 13 TAC stipulates the high contracting parties shall have determined and good faith to prevent disputes from arising. In case disputes on matters directly affect them should arise, especially disputes likely to disturb regional peace and harmony, they shall refrain from the threat or at all times settle such disputes among themselves through friendly negotiations. So, according to Article 13, the TAC in the event of a dispute that will disturb regional peace and security will avoid threats and the use of violence and will always resolve disputes between them through negotiations. It can be concluded from these provisions for ASEAN members in the event of a dispute, first avoiding the use of violence, second resolving disputes between ASEAN countries using negotiations.

Article 14 TAC reads to settle through regional processes, the high contracting parties shall constitute, as a continuing body, a high council comprising a representative of each of the high contracting parties to take cognizance of the existence of dispute or situations likely to disturb regional peace and harmony. According to this article to resolve disputes through a regional process, a will be formed High Council, which is a representative of member countries at the Ministerial level.

In Article 15 the TAC in the event no solution is reached through direct negotiations, the High Council shall take cognizance of the dispute and the situation shall recommend to the parties in dispute appropriate means of settlement such as good offices, mediation, inquiry or conciliation. The High Council may, however, offer its good offices, or upon agreement of the parties in dispute, constituting itself into a committee of mediation, inquiry or conciliation. When deemed necessary, the high council shall recommend appropriate measures for prevention of the deterioration of the dispute or the situation. In the event that the parties cannot resolve the dispute directly with negotiations, the High Council will advise the parties to the dispute on ways to resolve disputes such as good offices, mediation, inquiry, and conciliation. The High Council can offer its good services, or at the agreement of the parties to the dispute can form a mediator committee, inquiry committee, and conciliation committee. If it is deemed necessary the High Council can offer appropriate solutions to prevent worsening of disputes between the parties.

According to Article 16 the TAC, The foregoing provision of this chapter shall not apply to a dispute unless all parties to the dispute agree to their application to that dispute. However, this shall not include the other High Contracting Parties, not a party to the dispute from offering all possible assistance to settle the said dispute. Parties to the dispute should be well disposed towards such offers of assistance. Article 16 This TAC will only be applied if the parties to the dispute, approve the settlement of disputes regulated in the TAC to be used in their dispute. However, the High Council will not prohibit countries that are not parties to the dispute to offer peaceful remedies.

Article 17 of the TAC determines the possibility of resolving disputes under Article 33 paragraph 1 of the United Nations Charter. Article 17 The TAC states shall not include recourse to peaceful settlements contained in articles 33 paragraph 1 of the charter of 
the United Nations. The High Contracting Parties which are the parties to a dispute should be offered for in the charter of the United States.

From the above provisions, the settlement of disputes within the framework of ASEAN is:

1. Direct negotiation between the parties.

2. Through the High Council who can act as good offices, mediators or form inquiry committees or conciliation committees or take steps needed to resolve disputes.

3. Settling disputes in accordance with Article 33 of the United Nations Charter.

In Indonesia, the regulation regarding alternative dispute resolution and arbitration stipulated in Law Number 30 of 1999 concerning Arbitration and Alternative Dispute Settlement (hereinafter abbreviated to Arbitration Law), states 2 ways of resolving disputes outside the Court namely Arbitration is a method of resolving a civil dispute outside the General Court based on an arbitration agreement made in writing by the parties to the dispute; and Alternative Dispute Settlement is a dispute resolution or different opinions through a procedure agreed upon by the parties, namely an out of court settlement by Consultation, Negotiation, Mediation, Consolidation and Expert Assessment.

This section is the most important section of your article. The analysis or the results of the research should be clear and concise. The results should summarize (scientific) findings rather than providing data in great detail. Please highlight differences between your results or findings and the previous publications by other researchers.

\section{The Overview of the ASEAN Agreement on Transboundary Haze Pollution}

International dispute resolution can be carried out in various ways, namely peace, violence, and war. Peaceful settlement of disputes can be seen in Article 33 paragraph 1 of the UN Charter. Transboundary haze pollution is haze pollution originating from a country but the effect reaches other countries, usually until the source is difficult to distinguish. Moreover, both principles of state responsibility and unclean hands ${ }^{20}$ are commonly arising within this context and resulting the unclear 'target' who will be having the responsibility over the case.

Everyone has the right to a good and healthy environment, at least as guaranteed by international law. Also included in the principle of 21 Stockholm declarations which states the same thing, and such rights are protected by the right to file a lawsuit. These rights are also supplemented by the right to equal treatment. Although these rights also have limits. The principle of state responsibility in the case of transboundary pollution is that there is no instrument that regulates it. During this time responsibility Transboundary Pollution is still contractual obligations, whose implementation requirements are set out in detail in the treaty concerned or based on the concept of general state responsibility as stipulated in the ILC Draft Articles on State Responsibility if there has not been a treaty that specifically regulates it.21 After the burning of land and forest in 1997, the Environment Ministers of ASEAN countries

20 Listiningrum, Prischa. (2018). Transboundary Civil Litigation for Victims of Southeast Asian Haze Pollution: Access to Justice and the Non-Discrimination Principle. Transnational Environmental Law. 8(1): 24.

21 Dinarjati Ekapuspitasari and Agustina Merdekawati. (2007) "Pertanggungjawaban Indonesia dalam Penyelesaian Kasus Transboundary Haze Pollution Akibat Kebakaran Hutan Berdasarkan Konsep State Responsibility", Jurnal Mimbar Hukum, 19( 3): 474 
formulated regional plans to address the problem of forest fires. (Regional Action Plan Regional Action Plan) which later became the forerunner of the ASEAN Agreement on Transboundary Haze Pollution (AATHP). ${ }^{22}$

This treaty was signed on June 10, 2002, in Kuala Lumpur, Malaysia. At that time the signatory countries were Brunei Darussalam, Cambodia, Indonesia, Laos, Malaysia, Myanmar, the Philippines, Singapore, Thailand, and Vietnam. This treaty reiterates the ASEAN Declaration of August 8, 1967, which raises the spirit of regional cooperation among ASEAN countries. This treaty aims to mobilize the 1997 Haze Plan and the Hanoi Plan, which intends to implement the ASEAN Cooperation Plan in 1995 Crossborder Pollution, with the emphasis on the Fog Regional Plan Haze until 2001. The substance regulated in AATHP is the binding of cooperation between parties in ASEAN to resolve transboundary haze pollution problems.

\section{Forms of State Responsibility for Transboundary Haze Pollution After- AATHP Ratification}

In international law there are principles which explain that basically, a country has the same rights and obligations in terms of responsibility, this is stated in Article 3 ASEAN Agreement on Transboundary Haze Pollution (AATHP) regarding the principle previously explained that a country has the same rights and obligations towards environmental protection, safeguarding and utilizing the natural resources of their respective countries including forest and land resources by managing natural resources with ecological insight or environmentally friendly. The state is also responsible for all actions taken and ensures that actions taken do not cause damage to the environment and endanger human health from other countries or areas outside the national jurisdiction.

Addressing transboundary haze pollution caused by forest fires should involve all relevant parties, including local communities, non-governmental organizations, farmers and private companies. However, in AATHP it is not explained in detail about the responsibilities of the state, it can be seen from the absence of further articles on the form, mechanism, and consequences that can be given to a country that has caused forest fires in the national jurisdiction and proven to harm other countries outside of its national jurisdiction. Because there is no mention of the form and mechanism in the articles contained in the AATHP, the researcher will refer to the principles of general law, international agreements, jurisprudence, and laws relating to this issue.

The transboundary haze pollution due to forest fires is an action that touches the sovereignty of a country, in relation to the case of transboundary haze pollution, the country that is the source of pollution must be responsible for losses suffered by other countries. The principle of state responsibility in regard to a philosophical foundation cannot be separated from the absolute sovereignty of the state. In international law, the principle of state responsibility has a close connection with the existence of state sovereignty in international relations as one of the main principles. ${ }^{23}$ The basis of the sovereignty of each country is also strengthened by the existence of the doctrine of equality in international law. ${ }^{24}$ State responsibility is defined as an obligation that

22 Ayyappan Palanissamy, (2013), "Haze Free Air in Singapore and Malaysia-The Spirit of the Law in Southeast Asia", International Journal of Education and Research ,1(8):2

23 Deni Bram. (2011). "Pertanggungjawaban Negara Terhadap Pencemaran Lingkungan Transnasional", Jurnal Hukum, 18(2): 199

24 J.G Starke. (2006). Hukum Internasional, Jakarta: Sinar Grafika, p. 141 
must be carried out by a country to another country based on the command of international law.25 State responsibility in international law is used to describe the state's obligation to make reparations or full compensation for violations of these international obligations. ${ }^{26}$

State responsibility is regulated in the Draft Articles on State Responsibility for Internationally Wrongful Acts, despite the fact that the Draft Articles on State Responsibility for Internationally Wrongful Acts is not binding because it has not been established as a legal product. However, the strength of this Draft Articles on State Responsibility for Internationally Wrongful Acts is not viewed from the point of view of its form as a legal instrument, but is viewed from its contents and becomes an international customary law. As an international customary law, the Draft Articles on State Responsibility for Internationally Wrongful Acts is used as an additional and a binding source for implementing state responsibility. Based on Article 2 of the Draft Articles on State Responsibility for Internationally Wrongful Acts made by the International Law Commission, there are two elements that can be used as a basis for state responsibility if a country has taken legal actions that are wrong based on international law, namely:

1. Conducted by or can be attributed to the state within the framework of international law; and 27

2. It is clearly a violation of a country's international obligations. ${ }^{28}$

Furthermore, the country found guilty of causing harm to another country due to legal actions that are wrong based on international law, the country is obliged to carry out a form of responsibility internationally both with legal and diplomatic instruments. Pursuant to Article 31 of the Draft Articles on State Responsibility for Internationally Wrongful Acts, a country is responsible and provide reparations to the countries affected in this case is the impact of transboundary haze pollution. The reparations referred to are repairs to damage done, including all losses arising in the form of material or immaterial losses.29 There are three forms of reparation instruments contained in draft Article on State Responsibility for Internationally Wrongful Acts, namely:

a. Restitution is the act of recovery, restore or rebuild the situation to normal.

b. Compensation is to pay all the losses, the state responsible for the actions of an internationally has an obligation to provide compensation for the damage caused thereby, insofar as such damage is not done to restitution, ${ }^{30}$

25 Rebecca MM Wallace. (2002). International Law, London: Edisi Keempat, Sweet\&Maxwell, London,

26 Alah Khee-Jin Tan. (1999). “Forest Fires of Indonesia: State Responsibility and International Liability", The International and Comparative Law Quarterly, 48(4): p 828

27 International Law Commission, 2001, Draft Article on State Responsibility for Internationally Wrongful Acts, Article 2 paragraph (a)

28 International Law Commission, 2001, Draft Article on State Responsibility for Internationally Wrongful Acts, Article 2 paragraph (b)

29 International Law Commission, 2001, Draft Article on State Responsibility for Internationally Wrongful Acts, Article 31

30 International Law Commission, 2001, Draft Article on State Responsibility for Internationally Wrongful Acts, Article 36 paragraph 1 
compensation should cover any damages that may be assessed financially including loss of profit as far as it was established. ${ }^{31}$

c. Satisfaction is the settlement paid not in money, the state responsible for an internationally wrongful act has an obligation to give satisfaction for any injury caused by such action so far cannot be done well by restitution or compensation. ${ }^{32}$ Satisfaction here can consist of recognition of violations, a regret, and a formal apology or other appropriate modality. ${ }^{33}$ Satisfaction must not be out of proportion to injury and may not be in the form of responsible state insults. ${ }^{34}$

The three instruments must be fulfilled one by one or all three instruments at once. ${ }^{35}$ Indonesia in the case of haze pollution has been fully responsible. Indonesia can also utilize technical assistance and also financial assistance to overcome forest fires, this is based on Article 20 AATHP. In the case of haze pollution Indonesia fulfills its responsibilities in accordance with existing international legal practices, by way of Satisfaction formal or apologies and negotiations or negotiations, this is based on Article 37 of the Draft Articles on State Responsibility for Internationally Wrongful Acts, although basically an apology is a responsibility at the weakest level but it is also clear that apology is one of the best forms of state responsibility contained in the Draft Articles on State Responsibility for Internationally Wrongful Acts.

In international conventions ratified by Indonesia, the Biodiversity Convention and Climate Change Convention and the 1985 ASEAN Agreement on the Conservation of Nature and Natural Resources,1985 ASEAN Agreement on the Conservation of Nature and Natural Resources, which contains provisions that the state may exploit resources. Their nature, but is obliged to ensure that these activities do not cause damage in other countries (state responsibility), this provision has even become international customary law and is binding on all countries, even though it has been implemented since 1941 in the case of Trail Smelter (the US vs. Canada).

Based on the AATHP, the countries that are the cause of haze pollution cannot be asked for material or immaterial compensation because it is clearly explained in Article 3 of the AATHP in principle that the responsibility of the state is a joint responsibility of each ASEAN country that ratifies the AATHP agreement.

\section{The Mechanism for Dispute Settlement of Transboundary Haze Pollution in ASEAN After Ratification of AATHP Scope}

In accordance with Article 1 of the Draft Articles on State Responsibility for Internationally Wrongful Acts on state responsibility explains that "Every country that

31 International Law Commission, 2001, Draft Article on State Responsibility for Internationally Wrongful Acts, Article 36 paragraph 1

32 International Law Commission, 2001, Draft Article on State Responsibility for Internationally Wrongful Acts, 2001, Article 37 paragraph 1.

33 International Law Commission, 2001, Draft Article on State Responsibility for Internationally Wrongful Acts, Article 3737 paragraph 2.

34 International Law Commission, 2001, Draft Article on State Responsibility for Internationally Wrongful Acts, Article 3737 paragraph 3.

35 International Law Commission, 2001, Draft Article on State Responsibility for Internationally Wrongful Acts, Article 3737 paragraph 4. 
carries out an act that is detrimental to international law will result in responsibility in that country "But this is only limited by actions that violate international law.

The case of haze pollution caused by forest fires in Indonesia caused the neighboring countries to be affected by the fire, in this case, Indonesia received reprimands and appeals from those affected by the forest fires. However, reprimand, in this case, is the same as consultation and negotiation. Consultation and negotiation are the maintenance of peace which is a fundamental goal of the international law. Under Article 27 AATHP "Disputes between the Parties regarding interpretation or application, or fulfillment of this Agreement or Protocol, must be resolved peacefully through negotiations or negotiations". This article focuses on resolving through nonlitigation or peaceful way through consultation and negotiation in accordance with the provisions of international law relating to dispute resolution arrangements.

Treaty of Amity and Cooperation in Southeast Asia (TAC) regulates the settlement of disputes. In Article 13 the TAC regulates, "In the event of a dispute between the ASEAN Member States which would disturb the regional peace, the disputing party would avoid threatening and non-using actions. Violence. Disputes will be resolved through good and direct negotiations between the parties to the dispute ". Dispute resolution according to ASEAN Charter, Consultation is a dialogue between countries to find an agreement as in line with the recommendations from each party. Every purpose and basis for decision making must be built upon the consensus rather than on each party country. Furthermore, Negotiations, Negotiations are negotiations held directly between the parties with the aim of seeking a solution through dialogue without involving third parties. The dialogue is usually more colored by political considerations or legal arguments. If this process is successful, the results of the discussion will be stated in a document that is given legal force. For example, the results of the negotiation agreement are set out in the form of a peace agreement document.

\section{Conclusion}

AATHP did not explain in detail about the form of state responsibility for transboundary haze pollution, for this reason, the researcher uses three forms of reparations instruments contained in the Draft Articles on State Responsibility for Internationally Wrongful Acts, namely restitution, compensation, satisfaction. The mechanism for resolving disputes toward transboundary haze pollution within ASEAN is regulated in Article 27 AATHP "Disputes between the Parties regarding the interpretation or application, or fulfillment of this Agreement or Protocol must be resolved peacefully through negotiations or negotiations". If this process is successful, the results of the discussion will be stated in a document that is given legal force. For example, the results of the negotiation agreement are set out in the form of a peace agreement document.

\section{Acknowledgments}

The author thanks to Universitas Muhammadiyah Yogyakarta (UMY) especially for UMY Research, Publication, and Community Service Institute (LP3M) for financial supporting this research through Unggulan Prodi research scheme; and Agus Setyo Muntohar for the comments and supports on this article. 


\section{References}

Akbar Kurnia Putra. (2015) “Transboundary Haze Pollution dalam Perspektif Hukum Lingkungan Internasional", Jurnal Ilmu Hukum, 1(1):95

Alah Khee-Jin Tan. (1999). "Forest Fires of Indonesia: State Responsibility and International Liability", The International and Comparative Law Quarterly, 48(4): 828

Anon. (n.d.). Southeast Asian Haze. Reuters Graphics. Retrieved from http://graphics.thomsonreuters.com/15/haze/index.html (30 August 2019)

Anonim. (2015). Why Indonesia must ratify the ASEAN haze pollution treaty. Available online from http://www.thejakartapost.com/news/2013/07/14/whyindonesia-must-ratify-asean-haze-pollution-treaty.html. [Accessed March Maret 17,2015]

Ayyappan Palanissamy, (2013), "Haze Free Air in Singapore and Malaysia-The Spirit of the Law in Southeast Asia", International Journal of Education and Research, 1(8):2

Daniel Melling. (n.d). STATEMENT: Singapore's New Haze Pollution Law "A New Way of Doing Business". World Research Institute. https://www.wri.org/news/2014/08/statement-singapore\%E2\%80\%99s-newhaze-pollution-law-\%E2\% 80\%9C-new-way-doing-business $\% \mathrm{E} 2 \% 80 \% 9 \mathrm{D}$ August 2019).

Deni Bram. (2010). Pertanggungjawaban Indonesia terhadap pencemaran kabut asap di kawasan ASEAN (pendekatan economic analysis of law). Jurnal Hukum dan Pembangunan.40(40):231

Deni Bram. (2011) “Pertanggungjawaban Negara Terhadap Pencemaran Lingkungan Transnasional", Jurnal Hukum, 18(2): p 199

Dinarjati Ekapuspitasari dan Agustina Merdekawati. (2007) "Pertanggungjawaban Indonesia dalam Penyelesaian Kasus Transboundary Haze Pollution Akibat Kebakaran Hutan Berdasarkan Konsep State Responsibility", Jurnal Mimbar Hukum, 19(3): p 474

Helena Varkkey. (2013), "Patronage Politics, Plantation Fires and Transboundary Haze", Environmental Hazards, 12(3-4),201

International Law Commission, 2001, Draft Article on State Responsibility for Internationally Wrongful Acts

Jakarta Post. (2015). Why Indonesia must ratify the ASEAN haze pollution treaty. Available online from http://www.thejakartapost.com/news/2013/07/14/whyindonesia-must-ratify-asean-haze-pollution-treaty.html. [Accessed March Maret 17,2015]

Jerger, DavidB.Jr. (2014).Indonesia's Role in Realizing the Goals of ASEAN's Agreement on Transboundary Haze Pollution", Sustainable Development Law and Policy, 35

Kuala Lumpur Suara Karya. (2015). http: // www .suarakaryaonline. com/ news.html? id= $\underline{118116}$, [Accessed 17,March]

Law No. 26 of 2014 concerning Ratification of the ASEAN Agreement on Transboundary Haze Pollution.

Listiningrum, Prischa. (2018). Transboundary Civil Litigation for Victims of Southeast Asian Haze Pollution: Access to Justice and the Non-Discrimination Principle. Transnational Environmental Law. 8(1):24..

JG, Starke. (1992). Pengantar Hukum Internasional, Jakarta: Sinar Grafika 
JG Starke. (2006). Hukum Internasional, Jakarta: Edisi Kesepuluh, Sinar Grafika

Judith Mayer. (2006) "Transboundary Perspectives on Managing Indonesia's Fires", Journal of Environmental and Development, 15(2): 203

Kompas. (2015). Indonesia Ratifikasi soal Asap Lintas Batas, Available online from http://sains.kompas.com/\%20\%20read/2014/09/17/20032011/Indonesia. \%20\% 20Ratifikasi.soal.Asap.Lintas.Batas. [Accessed March Maret 17,2015]

KualaLumpurSuaraKaryaOnline.(2015).http://www.suarakaryaonline.com/news.htm $\underline{1 ? \mathrm{id}=118116}$, [Accessed 17, March]

Rebecca MM Wallace. (2002). International Law, London: Edisi Keempat, Sweet\&Maxwell

Siti Sundari Rangkuti. (2000). Hukum Lingkungan dan Kebijaksanaan Lingkungan Nasional. Surabaya: Airlangga University Press, Edisi Ketiga.

Sri Setianingsih Suwardi. (2006). Penyelesaian Sengketa Internasional, Jakarta: Universitas Indonesia (UI-Press)

Sucipto. (1985). Sistem Tanggung Jawab Dalam Pencemaran Udara, Malang

Supriadi. (2010). Hukum Lingkungan di Indonesia. Jakarta: Cetakan ketiga, Sinar Grafika.

Teddy Prasetiawan.( 2014), "Implikasi Ratifikasi AATHP Terhadap Pengendalian Kebakaran Hutan dan Lahan Indonesia", Info Singkat, VI:19/I/P3DI/Oktober/2014, Pusat Pengkajian, Pengolahan Data dan Informasi (P3DI), Sekretariat Jenderal DPR RI, Jakarta, VI(19):11.

Wan Fairus Wan Yacob et all. (2016), "The Impact of Haze on the Adolescent's Acute Respiratory Disease: A Single Institution Study". Journal of Acute Disease, , 5(3):27

Yordan Gunawan. (2014). Indonesian Responsibility for transboundary Haze Pollution After the Ratification Asean on Transboundary Haze Pollution (AATHP). Jurnal Media Hukum. 21(2): 170-177.

\section{Conflict of Interest Statement:}

The author(s) declares that the research was conducted in the absence of any commercial or financial relationships that could be construed as a potential conflict of interest.

Copyright $\odot 2019$ HALREV. All rights reserved. 